\title{
Improved clinical training of internal medicine students in hospital wards
}

\author{
Christian Bjurman* \\ Department of Internal Medicine, Halland's Hospital, Varberg, Sweden
}

Received: January 10, 2018

Accepted: January 21, 2018

Online Published: January 25, 2018

DOI: $10.5430 /$ jha.v $7 \mathrm{n} 1 \mathrm{p} 43$

URL: https://doi.org/10.5430/jha.v7n1p43

\begin{abstract}
Background: Clinical training (CT) in internal medicine wards is a compulsory part of the internal medicine courses in Sweden. Aim: To ask physicians responsible for different CT programs about the perceived quality of their programs and about ideas of improvement. Hypothesis: The average quality of local CT programs is generally perceived as low by responsible physicians. Methods: The author combined a literature review with own experiences to develop a novel quality assurance questionnaire aimed at improving the overall quality of CT. Eight geographically spread teaching hospitals were included in the study. Telephone interviews were conducted with responsible physicians. The interviews contained two parts: The questionnaire developed by the author containing twenty-seven 5-point rating scale questions on the quality of the local CT and open-ended questions about suggestions for improvement of the local teaching organization. Medians and percentage of maximum total score of the rating scale questions were calculated and improvements suggested by the participants were summarized.

Results: The average quality of the CT programs as measured by the total score of the developed questionnaire was $51 \%$ (of maximum 100\%) and varied between hospitals (range 33\%-65\%).

Conclusions: There seem to be a large potential for improvements in different CT programs. Improved collaboration between universities and teaching hospitals and the agreement on national standards could potentially improve the quality of CT in order to guarantee a uniform clinical education of high quality.
\end{abstract}

Key Words: Clinical training, Medical education, Teaching hospital, Quality improvement, Quality assessment questionnaire

\section{INTRODUCTION}

An increased amount of students study medicine in Sweden, ${ }^{[1]}$ and more hospitals have therefore been involved in clinical training (CT). One might assume that this has led to increased differentiation and implementation of new pedagogical ideas. However, the present quality of CT is unknown and should be regularly evaluated in order to guarantee a uniform clinical education of high quality.

In the following section a literature review regarding important components of high-quality CT that could be used as a checklist by doctors and hospital administrators to ensure high quality $\mathrm{CT}$ is presented.

\section{Literature review}

According to the literature optimal CT constitutes:

(1) Physicians involved in medical teaching being aware of the course objectives. ${ }^{[2]}$

(2) Understanding of the students' backgrounds. ${ }^{[3]}$

(3) Teaching in a genuine environment, that is authentic, in terms of the intended application of the learnt

\footnotetext{
*Correspondence: Christian Bjurman; Email: christian.bjurman@ regionhalland.se; Address: Department of Internal Medicine, Halland's Hospital, Träslövsv. 68, 43237 Varberg, Sweden.
} 
knowledge. ${ }^{[4]}$

(4) Bedside-teaching, including direct observation of the student during history taking and clinical examinations and questions to check the students' knowledge, aiming to achieve customized teaching, in relation to the students' individual needs. ${ }^{[5]}$ This method is also preferred by medical students to improve their clinical skills. $^{[6]}$

(5) Application of empiric teaching models, for example: TEACH (the supervisor thinks out loud and encourage the student to ask questions), ${ }^{[7]}$ SNAPPS (the student is requested to shortly summarize the patient's history in abstract terms and suggest two to three differential diagnoses), ${ }^{[8]}$ "the One-Minute Preceptor" (probing the student about relevant themes encountered in routine clinical work and discussion of related core topics) ${ }^{[9]}$ and Problem based learning (PBL) which aims at improving clinical skills ${ }^{[10]}$ and clinical reasoning (perception/interpretation, hypothesis generation, questioning/clinical examination, problem formulation and finally diagnostic/therapeutic decisions). ${ }^{[1]}$

According to one study (including 630 policlinic medical patients) $73 \%$ could be correctly diagnosed exclusively based on history and clinical examination, underscoring the importance of working with these skills. ${ }^{[12]}$ Medical students also prefer PBL in theoretical teaching. In PBL the teacher should initially present each session's objectives and relate teaching to students' prior knowledge. ${ }^{[13,14]}$ PBL teaching sessions should preferably include adapted patient cases to be solved by students, using already acquired knowledge and emergency medicine literature. Such interactive sessions have shown high acceptance among students. ${ }^{[15]}$

(6) Specific feedback to the students related to the course curriculum. ${ }^{[16,17]}$

(7) Teachers should also be offered formal pedagogical education and peer observation of teaching is recommended. ${ }^{[18,19]}$

However, clinicians involved in teaching often experience a conflict between teaching and the provision of routine care due to time restraints and the demand of high productivity. ${ }^{[20]}$ Teachers should therefore be allocated necessary time for teaching. [21]

\section{MATERial AND Methods}

Based on the literature review above the author developed a list of seven quality domains for teaching in hospital wards (see Table 1).
Table 1. Seven domains for quality of clinical teaching in hospital wards

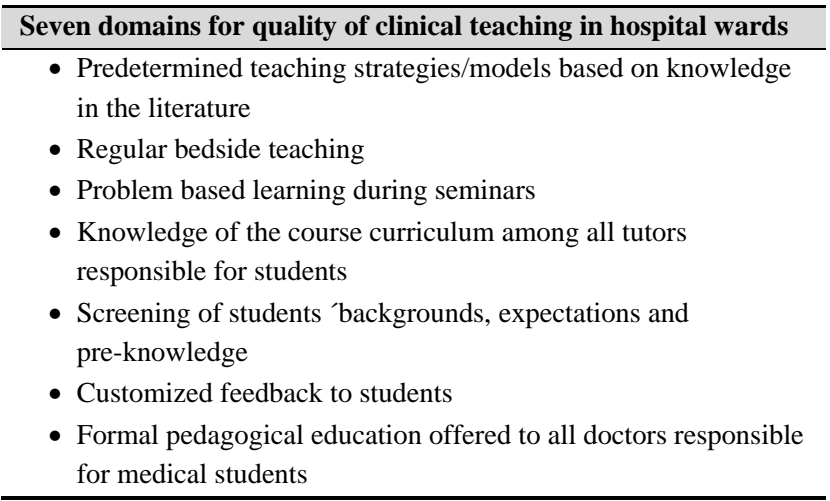

\subsection{Questionnaire}

In order to obtain comparability and a high response rate the author developed a questionnaire including twenty-seven statements regarding the quality of teaching, based on the seven domains above, which were adapted for telephone interviews (see Table 2). For each statement the participant rated, on a 5-point rating scale, to which extent the statement was in accordance with the local teaching environment.

\subsection{Participants}

Eight geographically spread teaching hospitals in Sweden (Borås, Enköping, Falun, Karlstad, Kungälv, Lidköping, Varberg and Sahlgrenska University hospital/site Mölndal) were included in the study. The hospitals range from small-size to mid-size hospitals in Sweden, and are providers of acute and elective routine care, and receive internal medicine students from the universities of Gothenburg, Uppsala and Örebro.

\subsection{Telephone interviews}

The author conducted all telephone interviews with the responsible clinicians for the local CT-programs. Additionally, as responsible for the CT-program in Varberg, the author also answered the same questions regarding the hospital of Varberg. Furthermore, the interviews contained open-ended questions on suggestions for quality improvement of CT through activities or organizational changes.

All participants were proved anonymity. Questionnaire responses and the suggestions for quality improvement were documented by the author.

\subsection{Statistical analyses}

The questionnaire responses were analyzed descriptively through medians and the percentage of maximum total score of all answered items (see Table 2) in Microsoft Excel 2010. The suggestions for improvement of CT were grouped and summarized under specific headings describing the suggested activity and its objectives (see Table 3 ). 
Table 2. Quality questionnaire for CT of internal medicine students

\begin{tabular}{|c|c|c|c|c|c|c|c|c|c|c|c|}
\hline Hospital & Median & Min & $\operatorname{Max}$ & 1 & 2 & 3 & 4 & 5 & 6 & 7 & 8 \\
\hline \multicolumn{12}{|l|}{ Work in medical wards } \\
\hline $\begin{array}{l}\text { - Doctors having students think out loud during the medical } \\
\text { rounds. }\end{array}$ & 3.5 & 2 & 4 & 4 & 4 & 3 & 2 & 3 & 4 & 4 & 3 \\
\hline $\begin{array}{l}\text { - Doctors on the wards actively encourage students to ask } \\
\text { questions during the working day. }\end{array}$ & 3.5 & 2 & 4 & 3 & 4 & 4 & 2 & 3 & 3 & 4 & 4 \\
\hline $\begin{array}{l}\text { - Students are encouraged to present newly admitted patients } \\
\text { and suggest 2-3 differential diagnoses. }\end{array}$ & 1 & 1 & 2 & 1 & 2 & 1 & 1 & 1 & 1 & 1 & 1 \\
\hline $\begin{array}{l}\text { - Responsible doctors explore the students' connection to } \\
\text { current topics encountered on the wards and discuss 1-2 key } \\
\text { principles. }\end{array}$ & 1.5 & 1 & 5 & 1 & 3 & 1 & 1 & 2 & 4 & 5 & 1 \\
\hline \multicolumn{12}{|l|}{ Bedside-teaching } \\
\hline $\begin{array}{l}\text { - Students get bedside teaching (apart from observing doctors } \\
\text { on the wards). }\end{array}$ & 4 & 1 & 5 & 5 & 2 & 1 & 1 & 5 & 3 & 5 & 5 \\
\hline \multicolumn{12}{|l|}{ Bedside teaching is regularly characterized by: } \\
\hline - Direct observation of students' communication with patients. & 2.5 & 1 & 4 & 2 & 2 & 1 & 1 & 3 & 3 & 3 & 4 \\
\hline - Direct observation of history taking. & 2.5 & 1 & 4 & 2 & 2 & 1 & 1 & 3 & 3 & 4 & 3 \\
\hline - Direct observation of clinical examinations. & 4 & 1 & 4 & 4 & 4 & 1 & 1 & 3 & 4 & & 4 \\
\hline $\begin{array}{l}\text { - Responsible doctors ask probing questions to students during } \\
\text { bedside teaching. }\end{array}$ & 3 & 1 & 4 & 3 & 2 & 1 & 1 & 4 & 4 & 3 & 4 \\
\hline \multicolumn{12}{|l|}{ Seminars } \\
\hline - Students attend seminars of at least 30 minutes. & 4 & 1 & 5 & 4 & & 1 & 4 & 2 & 4 & 3 & 5 \\
\hline \multicolumn{12}{|l|}{ Seminars are characterized by } \\
\hline $\begin{array}{l}\text { - The teacher initially presents overall objectives of the } \\
\text { seminar. }\end{array}$ & 3 & 2 & 5 & 3 & 3 & & 2 & 5 & 4 & 3 & 5 \\
\hline $\begin{array}{l}\text { - Clinical cases (authentic or constructed) are solved by the } \\
\text { students. }\end{array}$ & 3 & 1 & 5 & 4 & 4 & & 2 & 5 & 3 & 1 & 2 \\
\hline - Seminars are related to the students' pre-knowledge. & 4 & 2 & 5 & 3 & 5 & & 2 & 4 & 4 & 4 & 2 \\
\hline \multicolumn{12}{|l|}{ Objectives } \\
\hline - All supervisors know the overall objectives with CT. & 2.5 & 1 & 5 & 2 & 2 & 5 & 2 & 3 & 4 & 4 & 1 \\
\hline $\begin{array}{l}\text { - There is a written routine that, in detail, describes the } \\
\text { structure of CT at the teaching hospital. }\end{array}$ & 3 & 1 & 5 & 3 & 1 & 5 & 4 & 2 & 3 & 5 & 1 \\
\hline - All supervisors know the contents of the course curriculum. & 1 & 1 & 3 & 3 & 1 & 1 & 1 & 2 & 3 & 1 & 1 \\
\hline $\begin{array}{l}\text { - All supervisors are informed when changes take place in the } \\
\text { course design. }\end{array}$ & 2 & 1 & 5 & 2 & 1 & 2 & 2 & 1 & 4 & 5 & 1 \\
\hline \multicolumn{12}{|l|}{ Information about the students } \\
\hline $\begin{array}{l}\text { - Individual screening of students' backgrounds is always done } \\
\text { by doctors on the wards. }\end{array}$ & 2 & 1 & 3 & 3 & 2 & 1 & 1 & 1 & 3 & 3 & 2 \\
\hline $\begin{array}{l}\text { - Individual screening of students' expectations is always done } \\
\text { by doctors on the wards. }\end{array}$ & 1.5 & 1 & 3 & 2 & 1 & 1 & 1 & 1 & 3 & 2 & 2 \\
\hline $\begin{array}{l}\text { - Individual screening of students' pre-knowledge is always } \\
\text { done by the doctors on the wards. }\end{array}$ & 1.5 & 1 & 3 & 1 & 3 & 1 & 1 & 2 & 3 & 3 & 1 \\
\hline \multicolumn{12}{|l|}{ Feedback } \\
\hline - Students receive feedback. & 3 & 2 & 4 & 3 & 4 & 3 & 2 & 2 & 3 & 3 & 4 \\
\hline - Feedback is always specific. & 3 & 2 & 4 & 3 & 3 & 3 & 2 & 2 & 4 & 2 & 3 \\
\hline - Feedback is always connected to the course curriculum. & 2 & 1 & 5 & 2 & 2 & 5 & 2 & 1 & 3 & 2 & 1 \\
\hline - Teaching manuals are used. & 2 & 1 & 5 & 1 & 1 & 1 & 2 & 2 & 3 & 5 & 2 \\
\hline \multicolumn{12}{|l|}{ Teacher competence } \\
\hline - All supervisors have got formal education in teaching. & 3 & 2 & 4 & 3 & 4 & 3 & 2 & 3 & 2 & 3 & 3 \\
\hline - All supervisors get peer feedback on their teaching activities. & 1 & 1 & 4 & 1 & 1 & 1 & 1 & 1 & 2 & 1 & 4 \\
\hline \multicolumn{12}{|l|}{ Time for teaching } \\
\hline $\begin{array}{l}\text { - There is enough time for teachers to offer students good } \\
\text { teaching. }\end{array}$ & 2 & 1 & 4 & 1 & 1 & 3 & 1 & 2 & 4 & 2 & 4 \\
\hline - Number responses given & & & & 27 & 26 & 24 & 27 & 27 & 27 & 26 & 27 \\
\hline Percentage of maximum points (for given responses) & & & & $51 \%$ & $49 \%$ & $42 \%$ & $33 \%$ & $50 \%$ & $65 \%$ & $62 \%$ & $54 \%$ \\
\hline
\end{tabular}

Note. CT: Clinical training in internal medicine wards

Published by Sciedu Press 
Table 3. Suggestions for improvement of the organization of CT in hospital wards

\begin{tabular}{|c|c|}
\hline Suggested activity or organizational change & Objectives \\
\hline \multicolumn{2}{|l|}{ During introduction period } \\
\hline An information letter is sent to the students before arrival. & $\begin{array}{l}\text { - Decrease initial nervousness. } \\
\text { - Lead to a more effective and enjoyable introduction. } \\
\text { - Increase motivation and attendance to rules and regulations. }\end{array}$ \\
\hline Offer students one free lunch in hospital's canteen at the beginning of the rotation. & $\begin{array}{l}\text { - Create a positive atmosphere for learning. } \\
\text { - Students get an opportunity to express expectations and inform about } \\
\text { their individual backgrounds. }\end{array}$ \\
\hline $\begin{array}{l}\text { Welcome meeting with coordinated introduction of: Hospital wards, computerized } \\
\text { medical record system, dictation system, secrecy and sanitation routines. }\end{array}$ & $\begin{array}{l}\text { - Increase motivation and attendance to rules and regulations. } \\
\text { - Faster inclusion of students in regular everyday clinical work. }\end{array}$ \\
\hline $\begin{array}{l}\text { Students are requested to present themselves and tell staff why they are in the clinic and } \\
\text { what they want to learn. }\end{array}$ & - Increase learning. \\
\hline \multicolumn{2}{|l|}{ Structural improvements to increase knowledge about teaching and learning goals } \\
\hline Course curriculum is put on the walls of doctors' offices. & - Reminding everyone of learning objectives. \\
\hline $\begin{array}{l}\text { Important documents are put on the hospital's intranet: } \\
\text { Attendance forms, checklists with practical skills, feedback manuals. }\end{array}$ & - Quality management, more effective administration. \\
\hline $\begin{array}{l}\text { Objectives are presented at the beginning of each seminar and existence of prepared } \\
\text { education material. }\end{array}$ & - High quality education independent of seminar leader. \\
\hline \multicolumn{2}{|l|}{ Measures for Follow-up and Quality Assurance of clinical training } \\
\hline \multicolumn{2}{|l|}{$\begin{array}{l}\text { Daily seminars with clinical cases and subjects often encountered in regular clinical } \\
\text { work: }\end{array}$} \\
\hline $\begin{array}{l}X \text {-ray interpretation, contents and objectives with discharge summaries, feedback on } \\
\text { students' dictates, ECG interpretation, common medications, ethics (limited care, CPR), } \\
\text { "being in charge of the rounds", communication, handling of CPAP and defibrillator. }\end{array}$ & - Practicing and revising main objectives. \\
\hline A specific secretary responsible to transcribe dictates from all students. & - Guaranteeing that minimum requirements are met by all students. \\
\hline $\begin{array}{l}\text { A schedule with stand-ins for ordinary doctor responsible for CT. } \\
\text { Written routines for doctor in charge of students. }\end{array}$ & - Decrease risk of transient quality deficiencies. \\
\hline Written questionnaires are distributed to students after each rotation. & - Regular feedback and continuous adjustments. \\
\hline Recurrent follow-up meetings with groups of students at least once weekly. & $\begin{array}{l}\text { - Teaching site cares about their students' concerns. } \\
\text { - Offer opportunity for mutual reflection and exchange of ideas and } \\
\text { knowledge between students and teachers. }\end{array}$ \\
\hline
\end{tabular}

Note. CT: Clinical training in internal medicine wards
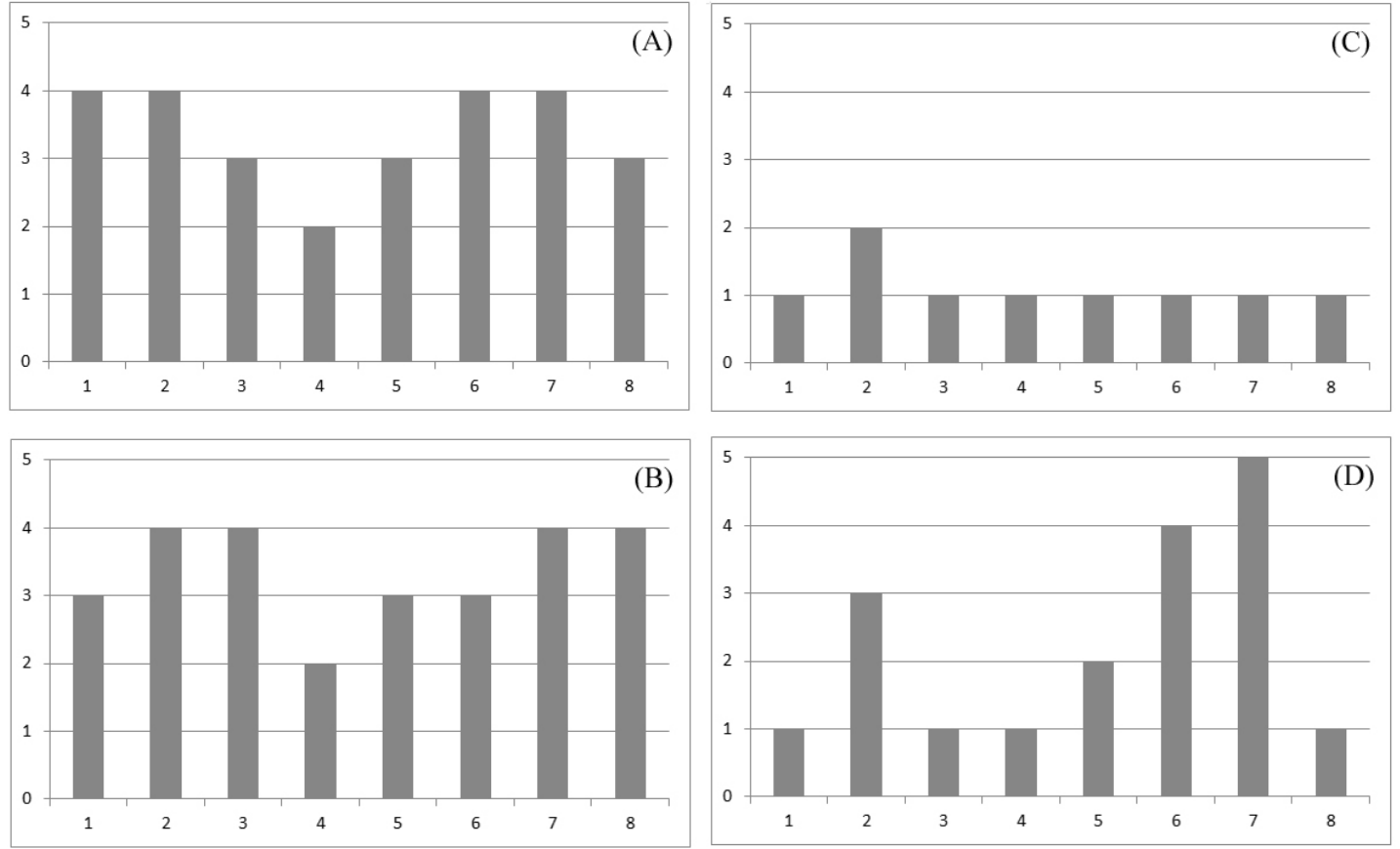

Figure 1. Graphical presentation of responses on the quality questionnaire regarding work in medical wards (A) Doctors having students think out loud during the medical rounds; (B) Doctors on the wards actively encourage students to ask questions during the working day; $(C)$ Students are encouraged to present newly admitted patients and suggest 2-3 differential diagnoses; (D) Responsible doctors explore the students' connection to current topics encountered on the wards and discuss 1-2 key principles 


\section{RESUlts}

The study participants answered 211 of 216 questions (98\%). The average of the total quality score as evaluated by the questionnaire was $51 \%$ and varied between hospitals (range, $33 \%-65 \%)$.

Despite highly variable results on single items, two strong (1-2) and five weak (3-7) areas could be identified (see Table 2 and Figures 1-8):

(1) Bedside teaching including the tutor's observation of students' practice of communication and examination skills was common.

(2) Seminars related to students' pre-knowledge were regularly conducted.
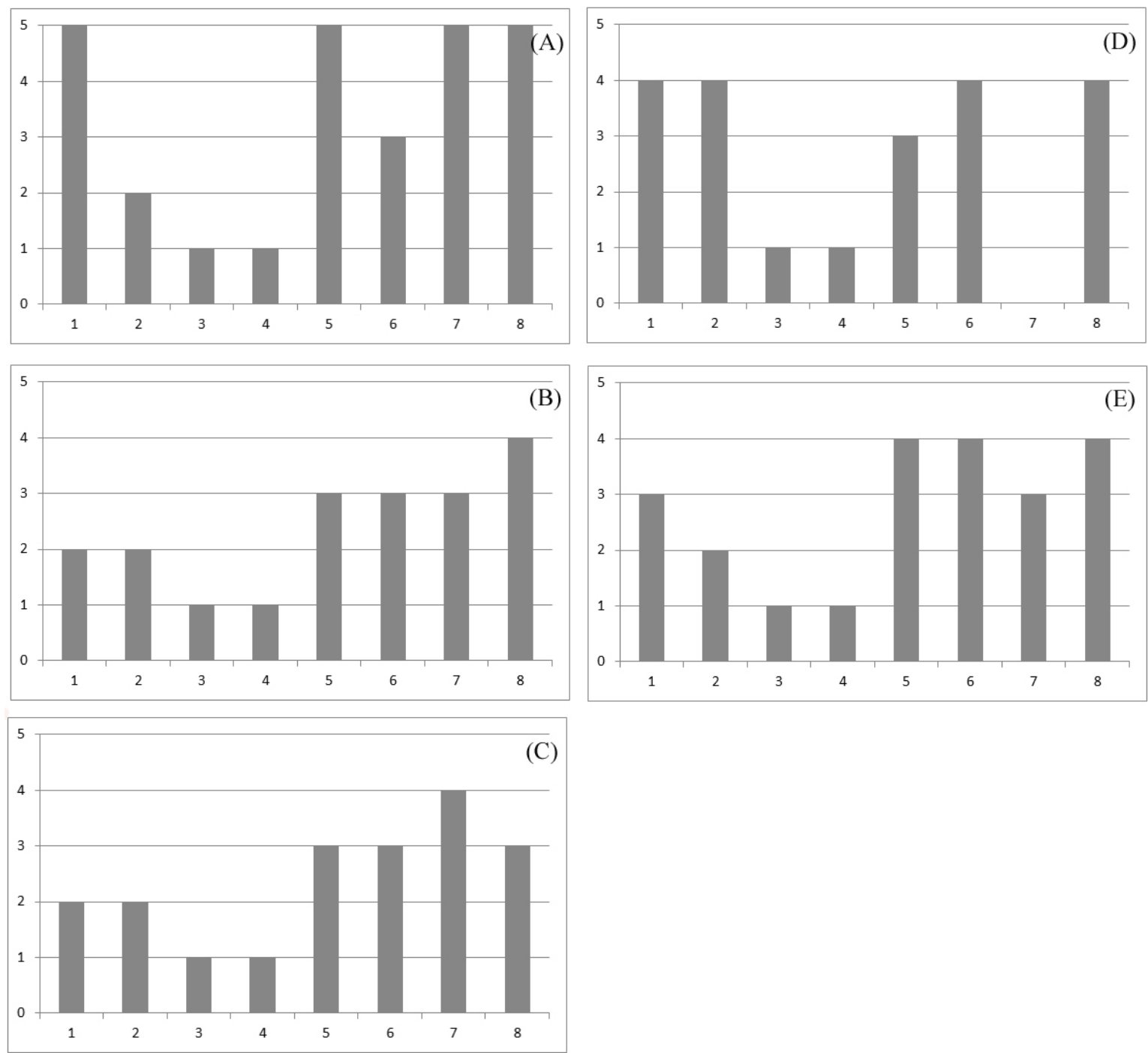

Figure 2. Graphical presentation of responses on the quality questionnaire regarding bedside teaching (A) Students get bedside teaching (apart from observing doctors on the wards); (B) Direct observation of students' communication with patients; $(C)$ Direct observation of history taking; (D) Direct observation of clinical examinations; (E) Responsible doctors ask probing questions to students during bedside teaching 

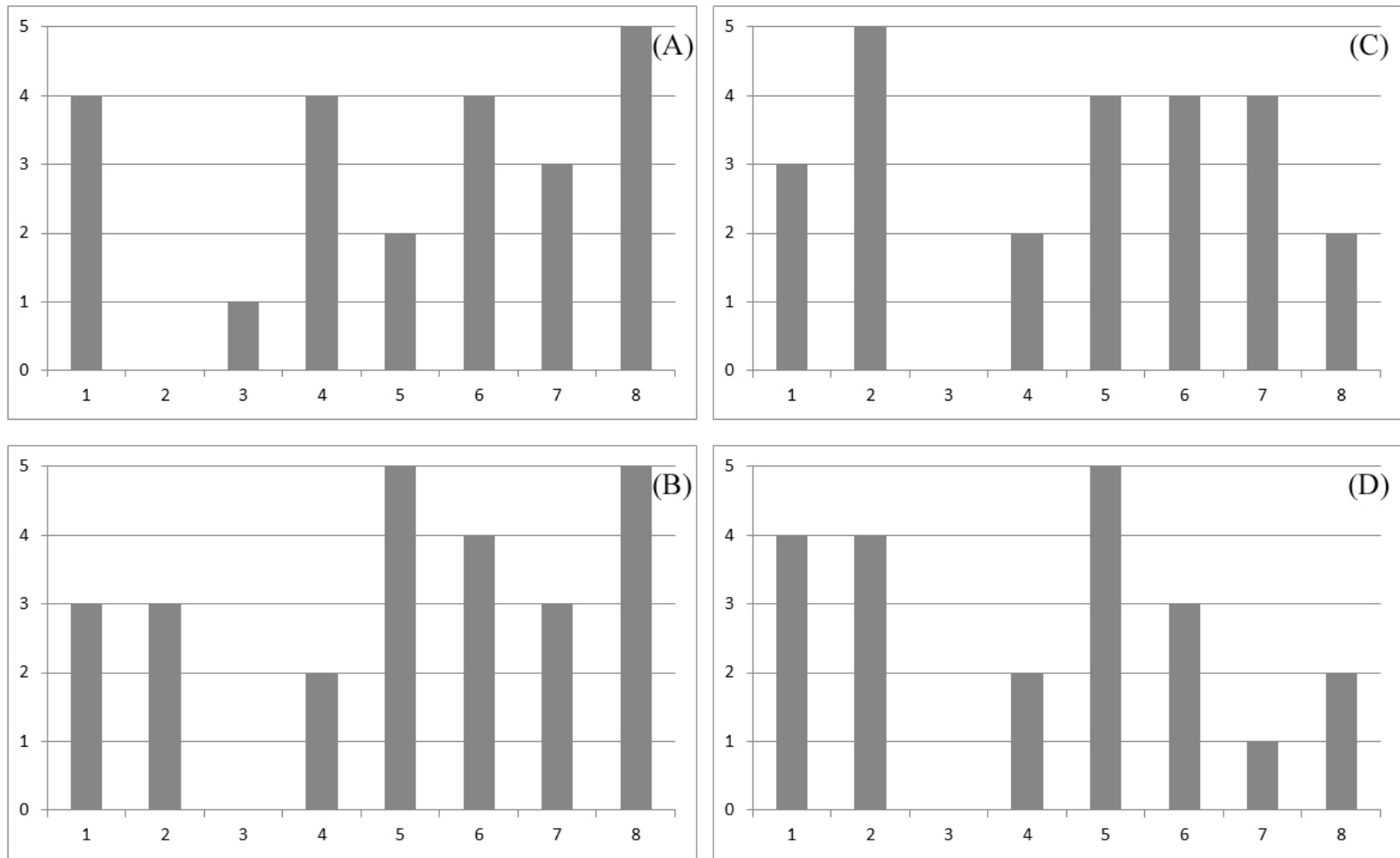

Figure 3. Graphical presentation of responses on the quality questionnaire regarding seminars

(A) Students attend seminars of at least 30 minutes; (B) The teacher initially presents overall objectives of the seminar; $(C)$ Seminars are related to the students' pre-knowledge; (D) Clinical cases (authentic or constructed) are solved by the students

The suggestions for improvement of CT by the participants are presented in Table 3. These included improvements during the crucial introduction period, structural improvements to increase knowledge about learning goals and measures for follow-up and Quality Assurance of CT. These activities and organizational changes intend to increase the transparency of objectives and to support the development of good relations and a positive learning climate through mutual feedback between teachers and students. Establishment of a standardized quality system with continuous documentation and evaluation of the learning progress was also suggested.

\section{Discussion}

The results of this study showed deficiencies at all participating teaching hospitals and a substantial variation in quality at the different training sites. Several areas of improvement for CT were identified.

The study's strengths was high response rates on the questionnaire items and detailed responses on questions regarding what constituted an optimal teaching organization. Since participants were guaranteed anonymity and blinding of the hospital name, the risk of social desirability was reduced. Because the questionnaire items were based on a literature review high face validity and content validity could be expected. ${ }^{[22]}$

Potential weaknesses of the study were: (1) That only the main representative at each teaching site (although given organizational and evaluative function) was interviewed and that no correlation analysis (due to few students at each site and risk of confounding) could be conducted between quality indicator items and students results on the final examination. However, high quality medical education, described in the literature, has in previous research been linked to success at the beginning of a medical career. ${ }^{[23]}$ (2) Also test-retest reliability was not assessed through a test-retest procedure, like administering the questionnaire to the participants again after a short period of time. However, this would probably not have changed the conclusions drawn. (3) Although we cannot be sure that the results on the questionnaire items are generalizable ${ }^{[24]}$ to all hospitals in Sweden, most of the collected ideas of improvement and quality indicators are certainly applicable to most hospitals involved in CT of medical students, independently of localization.

The variation in quality between teaching hospitals can be explained by the fact that there are, in Sweden, to date, no national guidelines for $\mathrm{CT}$ in internal medicine. The cur- 
rent shortage of time among clinicians involved in teaching, the limited knowledge about the course curriculum and the frequent lack of formal pedagogical education make it challenging for students to reach relevant knowledge for their future career.
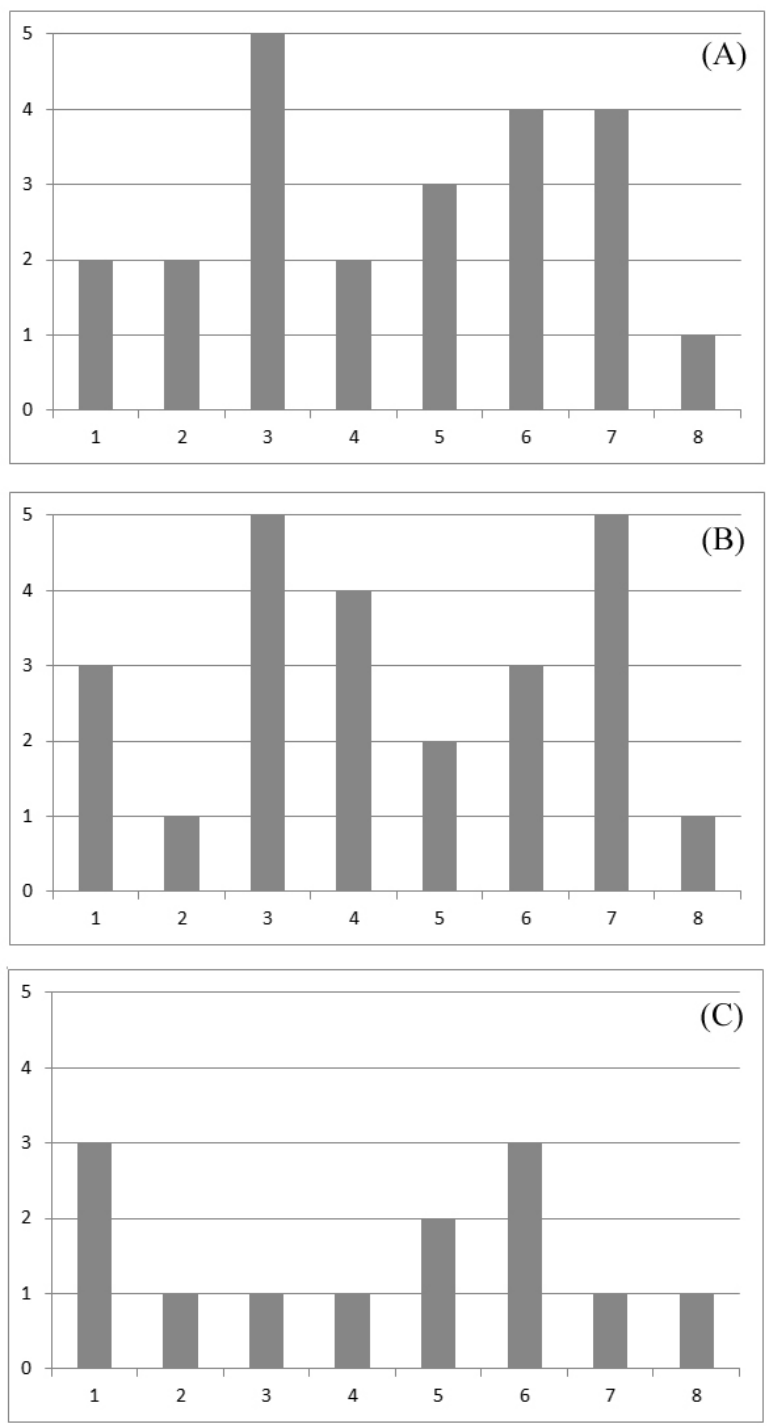

Figure 4. Graphical presentation of responses on the quality questionnaire regarding objectives

(A) All supervisors know the overall objectives with CT; (B) There is a written routine that, in detail, describes the structure of $C T$ at the teaching hospital; $(C)$ All supervisors know the contents of the course curriculum

In order to professionalize medical education, postgraduate courses (Master of Medical Education - MME) have been established in European Countries for more than 15 years. ${ }^{[25]}$ Subsequently national competency-based learning goal catalogs were developed, e.g. in Switzerland and Germany, in order to standardize the training content for medical students. ${ }^{[26,27]}$ In 2004 the World Federation for

Published by Sciedu Press
Medical Education (WFME) emphasized the need to define quality standards for medical training sites. ${ }^{[28]}$ The German Society for Medical Education published in 2014 a list of structure, process and outcome measures to define quality standards for decentralized training centers (teaching hospitals). ${ }^{[29]}$ International experiences showed that the use of logbooks in CT was useful to increase compliance to training standards. ${ }^{[30]}$ Other trends suggest that education could be improved by assignment of individual tutors to each student and the establishment of special student policlinics. ${ }^{[31]}$
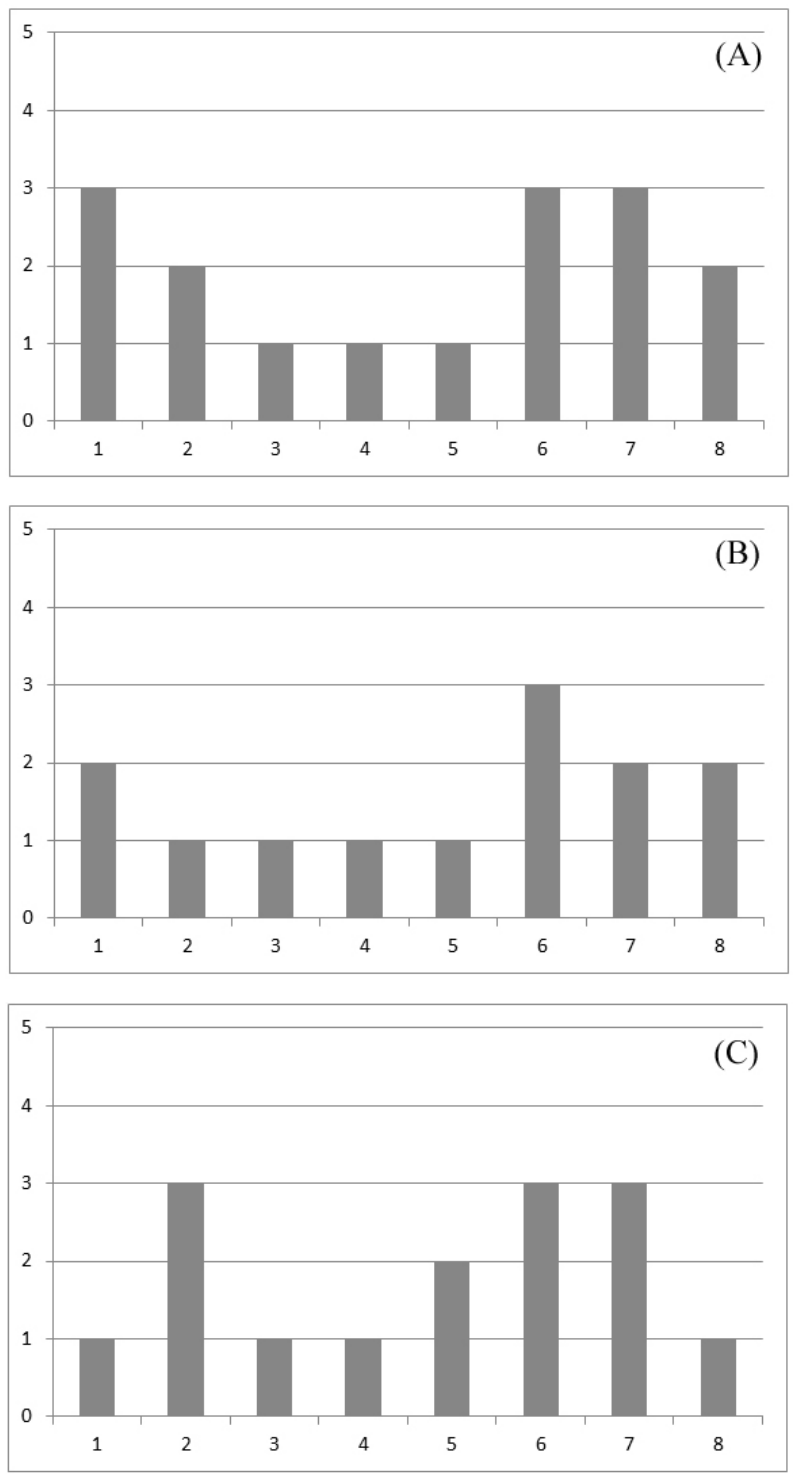

Figure 5. Graphical presentation of responses on the quality questionnaire regarding information about students (A) Individual screening of students' backgrounds is always done by doctors on the wards; (B) Individual screening of students' expectations is always done by doctors on the wards; $(C)$ Individual screening of students' pre-knowledge is always done by the doctors on the wards 

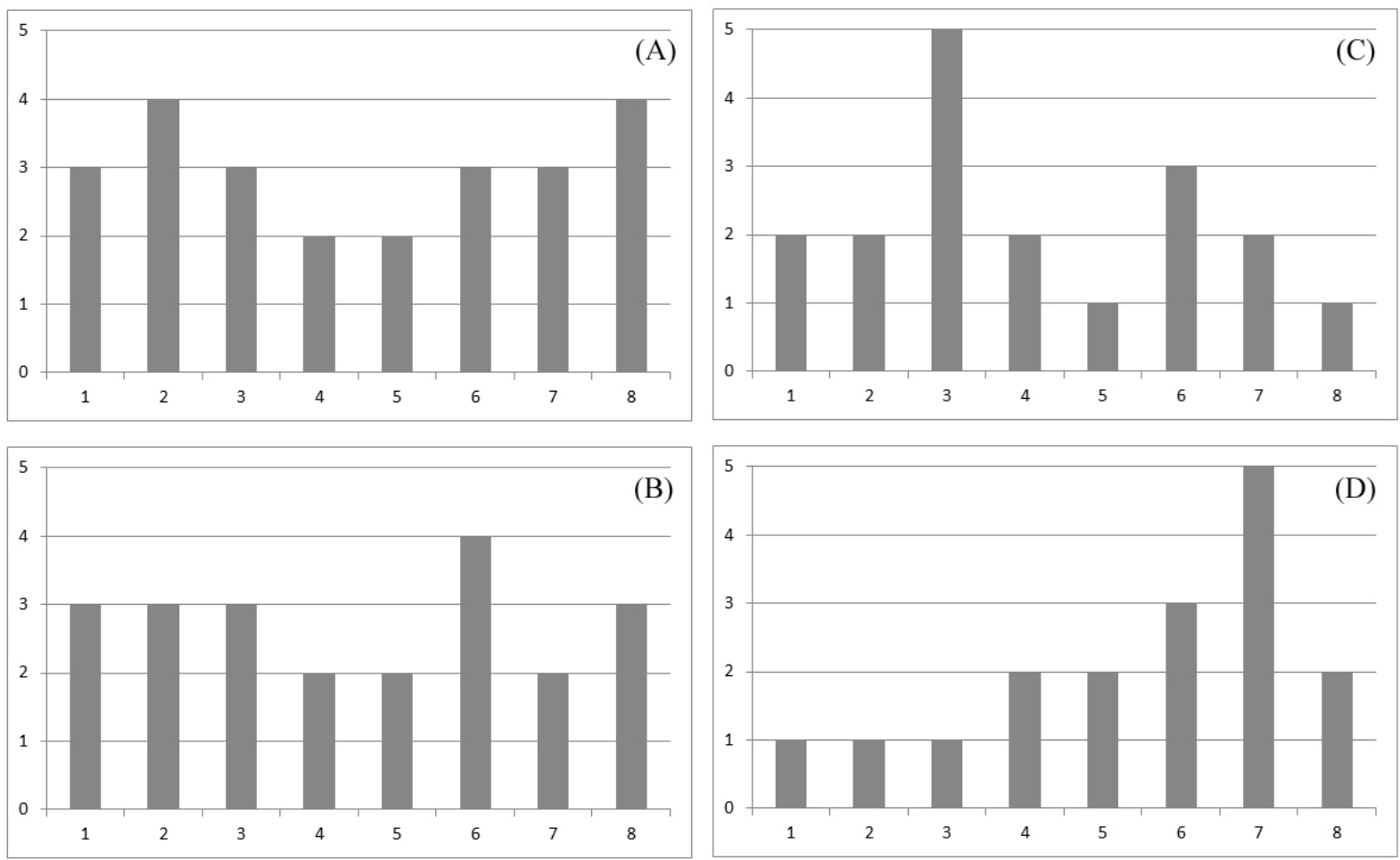

Figure 6. Graphical presentation of responses on the quality questionnaire regarding feedback (A) Students receive feedback; (B) Feedback is always specific; (C) Feedback is always connected to the course curriculum; (D) Teaching manuals are used
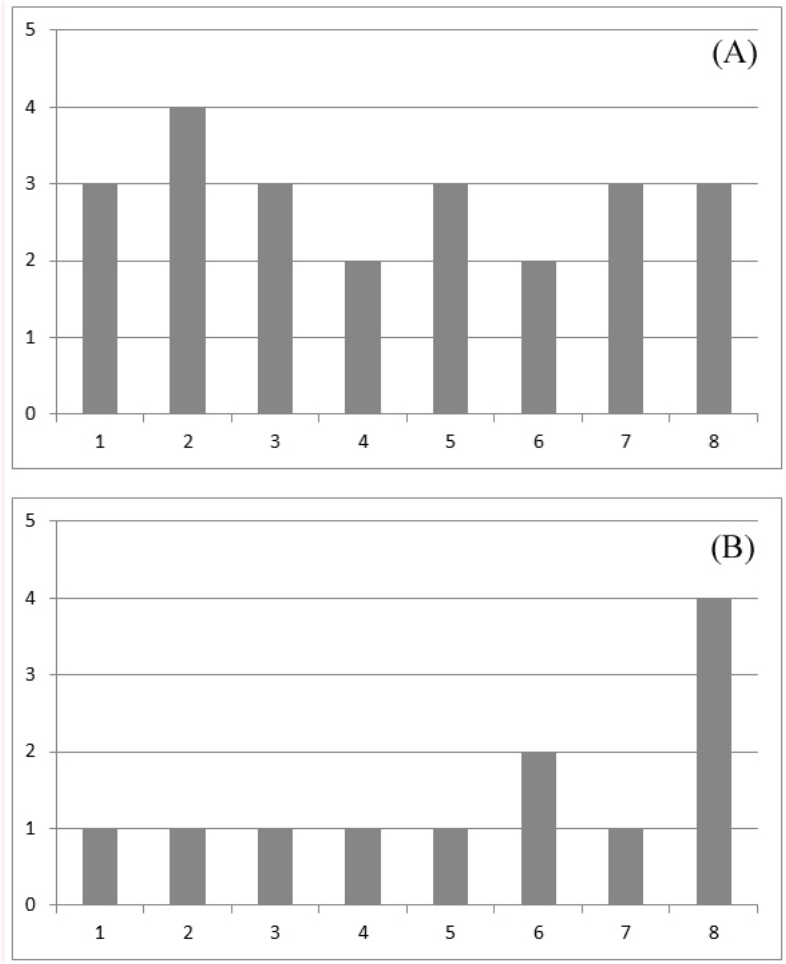

Figure 7. Graphical presentation of responses on the quality questionnaire regarding teacher competence

(A) All supervisors have got formal education in teaching; (B) All supervisors get peer feedback on their teaching activities

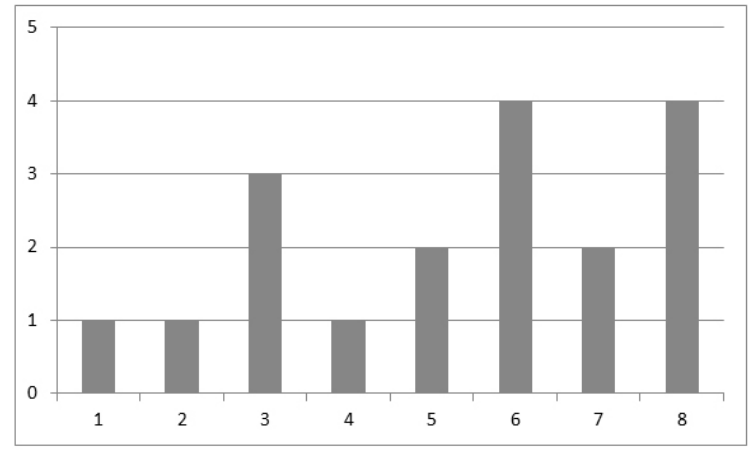

Figure 8. Graphical presentation of responses on the quality questionnaire regarding time for teaching There is enough time for teachers to offer students good teaching

\section{Conclusions}

Based on the above literature review and the interviews with responsible physicians at different teaching hospitals in Sweden, the author concludes that common CT quality standards can be defined. The following measures could potentially improve the quality of CT:

(1) A competency-oriented training curriculum should be defined by medical faculties together with the teaching hospitals.

(2) The curriculum should be made available to both students and teachers in the form of a logbook, which 
enables documentation of the student's progress.

(3) Didactic training of teachers, which should focus on effective transfer of learning objectives in real clinical situations at the bedside.

(4) Consistent feedback to students is of utmost importance.

(5) Tutoring of students by adequately prepared clinical teachers. Previous research also indicates that welltrained teachers do not perceive teaching as a timeconsuming effort.

In summary, the author suggests that quality assurance of clinical rotations should be undertaken through national initiatives including specification of formal requirements and standardization of learning objectives as well as regular follow-up of these standards, in order to guarantee clinical education of high quality.

Future research could include a reevaluation of sites that took part in this survey, to see if exam results and student satisfac- tion has increased in association with higher total scores on the questionnaire items. It would also be interesting to use the questionnaire in other countries to expand the survey to get additional input for improvements.

\section{ACKNOWLEDgements}

The author wants to thank the CT hospitals and the interview participants included in the study for their time and valuable contributions.

\section{ETHICS APPROVAL}

An ethical approval application was not deemed necessary by the local ethical committee in Gothenburg, Sweden.

\section{CONFLICTS OF INTEREST Disclosure}

$\mathrm{CB}$ is working at the hospital of Varberg (Hallands sjukhus Varberg) and has been responsible for the CT program there. $\mathrm{CB}$ also answered the questions regarding the hospital of Varberg.

\section{REFERENCES}

[1] Olsson Äärlaht M. Därför utbildas få läkare - trots brist [Therefore too few physicians are trained - despite shortage]. Göteborgs-Posten; Cited 2017 Jul 03. Available from: http://www.gp.se/nyheter/vastsverige/1.2431728-dar for-utbildas-fa-lakare-trots-brist

[2] Salam A, Siraj HH, Mohamad N, et al. Bedside teaching in undergraduate medical education: issues, strategies, and new models for better preparation of new generation doctors. Iran J Med Sci. 2011; 36: 1-6. PMid: 23365470.

[3] Roberts DH, Newman LR, Schwartzstein RM. Twelve tips for facilitating Millennials' learning. Med Teach. 2012; 34: 274-8. PMid: 22288944. https://doi.org/10.3109/0142159X.2011.6134 98

[4] Billet S. Situated learning: bridging sociocultural and cognitive theorising. Learning and Instruction. 1996; 6: 263-80. https: //doi.org/10.1016/0959-4752 (96)00006-0

[5] Janicik RW, Fletcher KE. Teaching at the bedside: a new model. Med Teach. 2003; 2: 127-130. PMid: 12745518. https ://doi .org/10 $.1080 / 0142159031000092490$

[6] Papanna KM, Kulkarni V, Tanvi D, et al. Perceptions and preferences of medical students regarding teaching methods in a Medical College, Mangalore India. Afr Health Sci. 2013; 13: 808-13. https://doi.org/10.4314/ahs.v13i3.41

[7] Smith DT, Kohlwes RJ. Teaching 228 strategies used by internal medicine residents on the wards. Med Teach. 2011; 33: e697-703. PMid: 22225453. https://doi .org/10.3109/0142159X. 2011. 611838

[8] Wolpaw TM, Wolpaw DR, Papp KK. SNAPPS: a learner-centered model for outpatient education. Acad Med. 2003; 78: 893-8. PMid: 14507619. https://doi.org/10.1097/00001888-200309000 $-00010$

Published by Sciedu Press
[9] Gallagher P, Tweed M, Hanna S, et al. Developing the One-Minute Preceptor. Clin Teach. 2012; 9: 358-62. PMid: 23167876. https: //doi.org/10.1111/j.1743-498X.2012.00596.x

[10] Oh SA, Chung EK, Han ER. The relationship between problem-based learning and clinical performance evaluations. Korean J Med Educ. 2015; 27: 195-200. PMid: 26330070. https://doi.org/10.394 6/kjme.2015.27.3.195

[11] Barrows HS, Tamblyn RM. Problem-Based Learning: An Approach to Medical Education. New York: Springer Publishing Company; 1980

[12] Sandler G. The importance of the history in the medical clinic and the cost of unnecessary tests. Am Heart J. 1980; 100: 928-31. https://doi.org/10.1016/0002-8703(80)90076-9

[13] Donner RS, Bickley H. Problem-based learning in American medical education: an overview. Bull Med Libr Assoc. 1993 Jul; 81(3): 294-8. PMid: 8374585.

[14] Malik AS, Malik RH. Twelve tips for effective lecturing in a PBL curriculum. Med Teach. 2012; 34: 198-204. PMid: 22364451. https://doi.org/10.3109/0142159X.2011.588741

[15] Böhme K, Luckner A, Mäder J, et al. PPI - Patient problems interactive: An approach for patient-centered teaching in small groups. ZFA. 2015; 91: 362-366.

[16] Providing Feedback to Medical Students [Internet]. Cited 2016 Oct 31. Available from: https://www.meded.umn.edu/meds/resou rces/documents/ProvidingFeedbacktoMedStudents .pdf

[17] Wood BP. Feedback: a key feature of medical training. Radiology. 2000; 215: 17-9. PMid: 10751460. https://doi.org/10.1148/ radiology.215.1.r00ap5917

[18] MED922 H17 Klinisk handledning av medicine studerande - pedagogiska aspekter [MED922 H17 Clinical instruction of medical students - pedagogical aspects]. GUL Göteborgs universitets lärplattform. Cited 2018 Jan 18. Available from: https://gul.gu.se/public/courseId/81914/coursePath /38212/38427/ecp/lang-sv/publicPage.do 
[19] Siddiqui ZS, Jonas-Dwyer D, Carr SE. Twelve tips for peer observation of teaching. Med Teach. 2007; 29: 297-300. PMid: 17786740. https://doi.org/10.1080/01421590701291451

[20] Yedidia MJ, Schwartz MD, Hirschkorn C, et al. Learners as teachers: the conflicting roles of medical residents. J Gen Intern Med. 1995; 10: 615-23. PMid: 8583264. https://doi.org/10.1007/BF02 602745

[21] Anvisningar för uppgörande av lärarnas arbetsplaner [Directions for teachers' schedules]. Cited 2016 Oct 31. Available from: http://www.abo.fi/personal/sv/media/3657/lara rnas_arbetstid_ii.pdf

[22] Bolarinwa OA. Principles and methods of validity and reliability testing of questionnaires used in social and health science researches. Niger Postgrad Med J. 2015; 22: 195-201. PMid: 26776330. https://doi.org/10.4103/1117-1936.173959

[23] Neely D, Feinglass J, Wallace WH. Developing a predictive model to assess applicants to an internal medicine residency. J Grad Med Educ. 2010; 2: 129-32. PMid: 21975899. https://doi .org/10.4 300/JGME-D-09-00044.1

[24] Leung L. Validity, reliability, and generalizability in qualitative research. Journal of Family Medicine and Primary Care. 2015; 4(3): 324-327. https://doi.org/10.4103/2249-4863.161306

[25] Science Council. Recommendations for the further development of medical studies in Germany on the basis of a survey of human medicine model studies (Drs. 4017-14). Dresden: Science Council; 2014.

[26] Hahn EG, Fischer MR. National Competence-Based Learning Objectives Medicine (NKLM) for Germany: Cooperation between the Society for Medical Education (GMA) and the Medical Faculty Society (MFT). GMS Z Med Ausbild. 2009; 26(3): Doc35.

[27] Bürgi H, Rindlisbacher B, Bader C, et al. Swiss Catalogue of Learning Objectives for Undergraduate Medical Training. 2008.

[28] Karle H. Global standards and accreditation in medical education: a view from the WFME. Acad Med. 2006; 81(12): 43-48. https://doi.org/10.1097/01. ACM.0000243383.71047.c4

[29] Raes P, Angstwurm M, Berberat P, et al. Quality management of clinical-practical instruction for Practical Year medical students in Germany - proposal for a catalogue of criteria from the German Society of Medical Education. Gms Zeitschrift Für Medizinische Ausbildung. 2014; 31(4): Doc49. PMid: 25489349.

[30] Schüttpelz-Brauns K, Narciss E, Schneyinck C, et al. Twelve tips for successfully implementing logbooks in clinical training. Medical Teacher. 2016; 38(6): 1. PMid: 26841068. https ://doi.org/10 .3109/0142159X . 2015.1132830

[31] Hammar M, Asp M, Berlin G, et al. Ny handlingsplan för bättre klinisk handledning av studenter [New action plan for improved clinical instruction of students]. Läkartidningen. 2006; 103: 649-54. PMid: 16583541. 